\title{
Profligate spending exploits wildlife in Taiwan
}

\author{
Chryssee Bradley Martin and Esmond Bradley Martin
}

\begin{abstract}
When the authors visited Taiwan in 1988 they discovered that much of the rhino horn on sale there had come from South Africa. Since then action by the South African Government and Taiwanese Customs has stopped these illegal imports. A return visit in 1990 revealed that the same is not true of horn from Asian rhinos; demand for this is increasing and wealthy Taiwanese, aware that prices will rise even higher as rhinoceros numbers decline, are buying it as an investment. Although imports of rhino horn have been prohibited in Taiwan since 1985, the smuggling goes on, encouraged by the fact that domestic sales of horn still continue despite a total ban initiated in 1989.
\end{abstract}

During a visit to Taiwan in 1988 (Martin and Martin, 1989), we discovered that the island had become the largest and probably the most expensive market in the world for African and Asian rhino horn. The African horn was coming almost entirely from South Africa, which not only supplied some of its own but also served as a conduit for horn from animals killed in Namibia, Mozambique, Zimbabwe, Zambia and Tanzania. Taiwanese professionals, businessmen and sailors imported it. Much of the Asian horn came from rhinos poached in Assam, India, but some Sumatran rhino horn from Sumatra and Borneo was also available, either directly or via traders in Singapore and Hong Kong (Martin and Martin, 1989).

The evidence that South Africa was the principal exporter of horn from black and white rhinos was derived almost entirely from the Taipei and Kaohsiung traders that we interviewed. Many South African conservationists denied at the time that their country was in any way involved with this illicit trade. However, after South Africa's role had been widely publicized, officials in the governments of South Africa, Namibia and Botswana took a greater interest in the matter and apprehended several middlemen. In October 1988, Botswana Customs and Excise seized a lorry en route to South Africa at the Kazungula ferry on the border between Botswana and Zambia. In a false compartment the officials found 94 rhino horns and a large consignment of ivory tusks. The lorry had started its journey in Zaire, but probably picked up the rhino horns in Zambia. In another court case it was proved that 18 black rhino horns weighing a total of $25 \mathrm{~kg}$ had been sent from South Africa to a Hong Kong trader in 1989, and he was found guilty, thanks to full co-operation from the South African authorities. Later that same year a Taiwanese resident of Cape Town was arrested for illegal possession of one rhino horn and 106 ivory tusks; it was reported that the trophies were intended to go to the Far East. To help with investigations of illegal trade, the South African Government set up the Endangered Species Protection Unit, manned by police, and several other caches of rhino horn have since been impounded in South Africa and Namibia.

We returned to Taiwan in April 1990, to try to discover whether the action by the South African government authorities had been sufficient to halt the smuggling of rhino horn and hide. Indeed, they have been successful. Since 1989, almost no African rhino horn has entered Taiwan from South Africa or anywhere else on the continent. Traders in Taiwan claim that the South African Government has made it very difficult to export the horn, and that Taiwanese Customs have also clamped down, checking consignments aboard flights from Johannesburg. Furthermore, Hong Kong traders, who used to be major buyers in Taipei, are no longer purchasing rhino horn there to sell to China. In fact, the demand for 
African rhino horn in Taiwan has now considerably declined. There is under half as much available in the medicine shops as there was in 1988, and Taipei's average retail price for African rhino horn is $\$$ US439 cheaper per $\mathrm{kg}$ than it was in 1988 , despite a 10 per cent appreciation in value of the local currency against the US dollar (Table 1).

On the other hand, the demand for Asian rhino horn, which the Taiwanese prefer, believing it to be superior to African in medicinal properties, has continued to increase since 1988. New supplies are still coming in via Hong Kong, Indonesia and India, and the Taiwanese, having ample cash to offer the world's highest prices, are buying it not only to cure ailments but also as an investment. They feel certain that the price will escalate further, due to the continuing decline in rhino numbers and are now paying a phenomenal $\$ \mathrm{US45,000}$ wholesale per $\mathrm{kg}$ for Indian horn. This has had an adverse effect on conservation in Assam where 58 rhinos were killed in 1989, with the poachers receiving the equivalent of $\$ \mathrm{US6250}$ per $\mathrm{kg}$ as compared to \$US2600 in 1986.

Taiwanese self-made millionaires are notorious for their conspicuous consumption of rare and exotic wildlife, and the Chinese traditional adage that animals exist primarily for

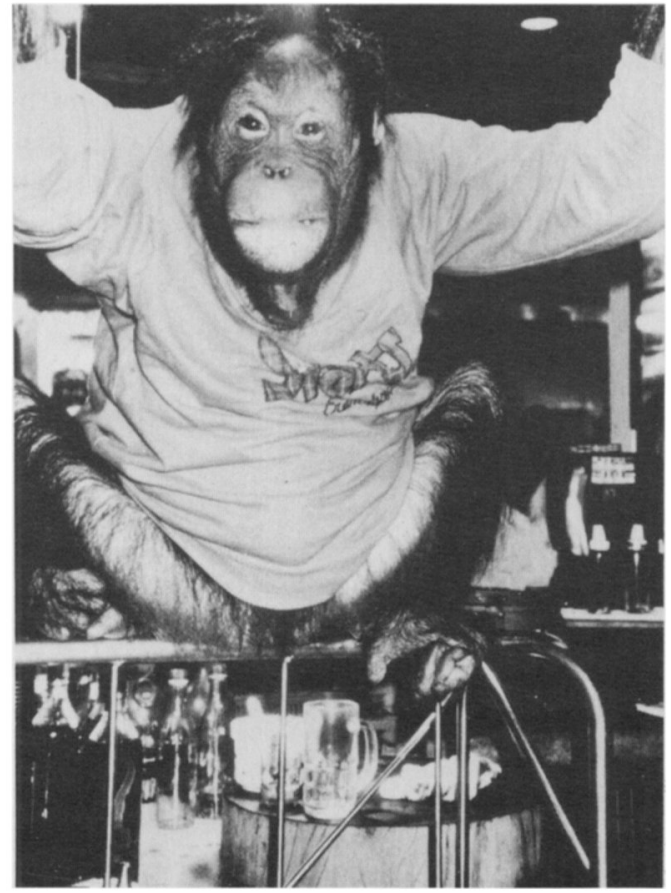

This orang-utan is put on display to attract customers to a market stall selling meat, blood and penises from snakes and other reptiles as aphrodisiacs (Chryssee Martin).

exploitation is nowhere more pronounced than on this island. Ways of making use of wildlife are more important than trying to

Table 1. Average retail prices for rhinoceros horn in Taiwan

\begin{tabular}{|c|c|c|c|c|c|}
\hline Year & Place & $\begin{array}{l}\text { No. pharmacies } \\
\text { visited }\end{array}$ & $\begin{array}{l}\text { No. (per cent) } \\
\text { selling horn }\end{array}$ & $\begin{array}{l}\text { Type of } \\
\text { horn }\end{array}$ & $\begin{array}{l}\text { Average price } \\
\text { per kg (\$US) }\end{array}$ \\
\hline \multirow[t]{2}{*}{1979} & Taipei & 9 & $9(100)$ & African & 1,596 \\
\hline & & & & Asian & 17,090 \\
\hline \multirow[t]{2}{*}{1985} & Taipei & 34 & $26(76)$ & African & 1,532 \\
\hline & & & & Asian & 23,929 \\
\hline \multirow[t]{2}{*}{1988} & Taipei & 60 & $44(73)$ & African & 4,660 \\
\hline & & & & Asian & 40,558 \\
\hline \multirow[t]{2}{*}{1990} & Taipei & 79 & $40(51)$ & African & 4,221 \\
\hline & & & & Asian & 54,040 \\
\hline \multirow[t]{2}{*}{1985} & Kaohsiung & 20 & $18(90)$ & African & 2,077 \\
\hline & & & & Asian & 21,365 \\
\hline \multirow[t]{2}{*}{1988} & Kaohsiung & 15 & $13(87)$ & African & 3,347 \\
\hline & & & & Asian & 42,880 \\
\hline \multirow[t]{2}{*}{1990} & Kaohsiung & 14 & $7(50)$ & African & 3,737 \\
\hline & & & & Asian & 40,404 \\
\hline
\end{tabular}

Source: Authors' surveys. 
save it, so social prestige is gained as an owner of exotic pets such as orang-utans, black bears and arowana fish. Status is also exhibited by businessmen in restaurants who flaunt their wealth by ordering stewed bear paws or having waiters sprinkle gold dust over their steaks.

These examples of profligate spending illustrate the need in Taiwan to close down all avenues allowing the purchase of endangered wildlife and its products. The 1985 ban against rhino horn and hide imports had been ineffectual at least partly because these products could still be traded internally. We urged the banning of domestic sales some years ago, conforming to the CITES Resolution Conf. 6.10 , which has been enacted in Hong Kong

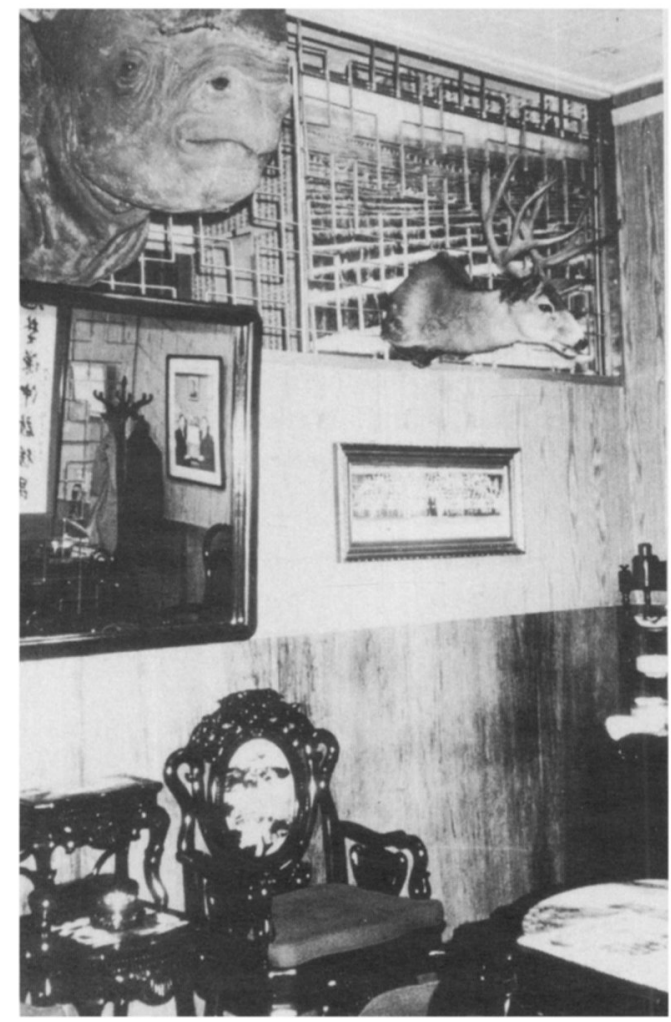

The most ornate consultation room we have seen in any traditional pharmacy is this one in Taiwan Mounted heads of animals used for medicinal purposes loom over the clients while they sit on replicas of imperial Chinese chairs (Chryssee Martin).

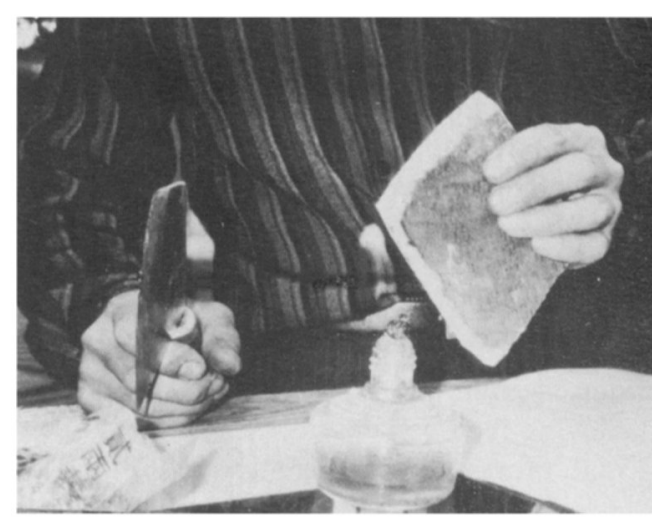

Most rhinoceros hide for sale in Taiwan comes from white rhinos. In early 1990 the average retail price for one $\mathrm{kg}$ in Taipei's pharmacies was \$US270. This piece is being heated to make it more malleable for cutting into slices (Chryssee Martin).

and Macao with success. Taiwan's Legislative Yuan passed the Wildlife Protection Act in June 1989, which bans and imposes penalties, including fines and detention, for catching, maltreating, killing, importing, trading, exchanging or attempting to display any endangered species or parts thereof. However, the authorities have not yet put it into practice. In a night market we saw young orangutans being used to attract customers to booths where snakes and terrapins were slaughtered to provide aphrodisiac potions; we were invited to play with a bear in a cage behind a fitness centre; a diplomat told us he had recently been offered a baby orang-utan on a street corner in the middle of the capital city; and, although the amount of rhino horn available in the medicine shops was less than we had found previously, it was still publicly displayed and for sale to anyone who wished to purchase it.

\section{Reference}

Martin, E.B. and Martin, C.B. 1989. The Taiwanese connection-a new peril for rhinos. Oryx, 23, 76-81.

Esmond and Chryssee Bradley Martin, P.O. Box 15510 Mbagathi, Nairobi, Kenya. 